\title{
Seroprevalence of immunoglobulin G antibody to parvovirus B19 in Ontario
}

\author{
SAMIA WASFY MB BCH DCH DPH, JOHN NISHIKAWA BSc MLT, MARTIN PETRIC PhD SCM(CCM)
}

\begin{abstract}
S WASFY, J NISHIKAWA, M PETRIC. Seroprevalence of immunoglobulin G antibody to parvovirus B19 in Ontario. Can J Infect Dis 1996;7(5):313-316. The prevalence of antibody to parvovirus B19 was assessed in two populations. In a group of 494 residents from Ontario and the Maritimes, virus-specific immunoglobulin (Ig) M antibody, a marker of acute infection, was found throughout the year but was most prevalent during the late winter and early spring months. The overall prevalence of IgG antibody in this group was 30.3\%. In an effort to examine age-specific prevalence in this population, a second group of sera from 210 pediatric patients at The Hospital for Sick Children, Toronto, Ontario and from Red Cross blood donors was tested for the presence of B19-specific IgG, and of these, $31.4 \%$ of the samples were positive. This prevalence varied from $3.3 \%$ in the under five-year-old age group to $66.7 \%$ in the 35 - to 45 -year-old age group. Eighty per cent of sera from females of this group were seropositive. This study provides insight into the prevalence of parvovirus B19 IgG antibody in the population.
\end{abstract}

Key Words: Human parvovirus B19, Seroprevalence

\section{Séroprévalence des anticorps anti-immunoglobuline $\mathrm{G}$ dirigés contre le parvovirus B19 en Ontario}

RÉSUMÉ : La prévalence de l'anticorps dirigé contre le parvovirus B19 a été évaluée auprès de deux populations. Dans un groupe de 494 résidents de l'Ontario et des provinces Maritimes, un anticorps dirigé contre l'immunoglobuline M (Ig) spécifique au virus, un marqueur de l'infection aiguë, a été observé tout au long de l'année, mais s'est révélé plus prévalent vers la fin de l'hiver et durant les premiers mois du printemps. La prévalence globale de l'anticorps IgG dans ce groupe était de 30,3\%. Afin d'examiner la prévalence spécifique selon l'âge chez cette population, un deuxième groupe d'échantillons sériques provenant de 210 patients pédiatriques du Hospital for Sick Children de Toronto et de donneurs de la Croix-Rouge a été analysé pour y déceler la présence de l'IgG spécifique au B19 et 31,4\% des échantillons se sont révélés positifs. Cette prévalence allait de $3,3 \%$ chez les moins de 5 ans à $66,7 \%$ chez les individus âgés de 35 à 45 ans. Quatre-vingt pour cent des échantillons sériques provenant de femmes de ce groupe étaient séroposifs. Cette étude permet d'alimenter la discussion sur la prévalence de l'anticorps anti-IgG dirigé contre le parvovirus B19 chez cette population.

$\mathrm{H}$ uman parvovirus B19 is now well established as the causative agent of erythema infectiosum (fifth disease) in children, arthropathy in adults, and nonimmune fetal hydrops and still birth in pregnant women (1-5). In children with hemoglobinopathies, such as sickle cell disease, infection with parvovirus B19 may result in the development of aplastic crisis, and in immunodeficient patients, the infection may become chronic and result in persistent anemia (6-9). However, asymptomatic infections have been well documented $(10,11)$. Parvovirus B19 infections have been reported worldwide

Virology Laboratory, Division of Microbiology, The Hospital for Sick Children, Toronto, Ontario

Correspondence and reprints: Dr Martin Petric, Virology Laboratory, The Department of Microbiology, The Hospital for Sick Children, 555 University Avenue, Toronto, Ontario M5G 1X8. Telephone 416-813-6111, fax 416-813-5993

Received for publication November 29, 1995. Accepted March 25, 1996 
Wasfy et al

TABLE 1

Parvovirus B19 serology from sera received between May 1993 and April 1994

\begin{tabular}{|c|c|c|c|c|c|}
\hline Month & Total & IgG & IgM & $\lg G+\operatorname{Ig} M$ & Nonreactive \\
\hline May & 41 & 8 & 2 & 9 & 22 \\
\hline June & 63 & 24 & 0 & 8 & 31 \\
\hline July & 35 & 10 & 1 & 0 & 24 \\
\hline August & 24 & 6 & 0 & 3 & 15 \\
\hline September & 26 & 9 & 1 & 3 & 13 \\
\hline October & 14 & 2 & 0 & 2 & 10 \\
\hline November & 25 & 7 & 0 & 5 & 13 \\
\hline December & 29 & 6 & 1 & 2 & 20 \\
\hline January & 31 & 3 & 2 & 4 & 22 \\
\hline February & 54 & 8 & 5 & 7 & 34 \\
\hline March & 49 & 12 & 5 & 14 & 18 \\
\hline April & 103 & 25 & 5 & 19 & 54 \\
\hline Total & 494 & 120 & 22 & 76 & 276 \\
\hline Percentage of total & & 24.3 & 4.7 & 15.3 & 55.8 \\
\hline
\end{tabular}

Ig Immunoglobulin

throughout the year, with springtime epidemics occurring with a periodicity of five to seven years and lasting two to six months $(6,7)$. Infections happen in all age groups, but they are most common among school children (12). Up to $50 \%$ of household contacts and $10 \%$ to $60 \%$ of children in a school setting may manifest symptoms of infection $(7,12)$. In serosurveys in the United States the prevalence of antibody to parvovirus B19 was shown to increase with age from $2 \%$ in children under 5 years to $49 \%$ in adults over 20 years of age $(13,14)$. Because no comparable information is available on the Canadian population, the following studies on seroprevalence of the antibody to parvovirus B19 were undertaken using sera predominantly from Ontario.

\section{PATIENTS AND METHODS}

Study populations: Sera from two distinct groups were examined. The first consisted of 494 sera samples submitted to the Virology Laboratory at The Hospital for Sick Children in Toronto, Ontario, between May 1, 1993 and April 30, 1994, for the determination of parvovirus B19 immunoglobulin (Ig) G and IgM status. In general, these subjects, of whom $81 \%$ were females, were suspected of either having a parvovirus B19 infection or having been in contact with a patient who was thought to have erythema infectiosum or who had been exposed to a case of this illness. These sera were collected mainly in the Toronto area, but included specimens from other parts of Ontario and specimens from Nova Scotia and New Brunswick. Specimens from the Maritimes accounted for $11.3 \%$ of the sera in this group. Because these sera came from subjects in some way associated with clinical illness, a second group who would better represent the general population was selected. This group of 210 subjects was randomly selected by sex. The subjects' ages ranged from under one month to 65 years. Sera came from two sources: immunocompetent pediatric in- and out-patients up to 18 years of age who were being treated for illnesses other than rashes, and adult Red Cross blood donors from the Ontario population who were available from a previous study (15).

Parvovirus B19 antibody determination: Indirect IgG and
IgM antibody capture enzyme immunoassays (EIAs) were employed throughout the study $(13,14)$. Immulon 2 (Dynatech Inc, Virginia) flat bottom plates were coated with goat antihuman IgG or IgM (Tago Immunologicals, California) to form an antibody capture solid phase. The test sera, together with the high and low positive as well as the negative controls, were tested at a dilution of 1:50 in phosphate buffered saline (PBS), Tween $20(0.15 \%)$ and gelatin $(0.5 \%)$. All the washing steps were performed with PBS-Tween 20. The baculovirusexpressed recombinant parvovirus B19 antigen was provided as a gift by Dr M Collett (Medimmune Inc, Maryland) (16) and the monoclonal antibody to parvovirus B19 was provided by $\mathrm{Dr}$ DA Kennedy (Laboratory Centre for Disease Control, Ottawa). The peroxidase conjugated goat anti-mouse antibody (Kirkegaard and Perry Laboratories, Maryland) was used with ortho-phenylenediamine as a chromogen and the reactions were monitored for absorbance at $414 \mathrm{~nm}$. Sera were considered positive for human parvovirus antibody if the absorbance was greater than 0.025 and the ratio of the values for the positive to negative control standards was greater than 2.00 for IgG and 2.1 for IgM. Sera with absorbance twice the negative control but between 0.020 and 0.030 were retested, and if the above values persisted were considered negative for the purposes of this study. There were $37(7.5 \%)$ such indeterminate samples from the first group of 494 specimens and $12(5.7 \%)$ from the second group of 210 specimens. The first group had five sera with an indeterminate IgM status. The results of the above studies were therefore designated either as positive or negative and analyzed by age group and sex. The analysis was subjected to $\chi^{2}$ test analysis; $\mathrm{P} \leq 0.05$ was considered significant (17).

The EIA described above had been used in the hospital laboratory since 1991 and was retrospectively compared with the commercial Biotrin (Ireland) enzyme immunoassay when the Biotrin assay became available. In this comparison, the Biotrin assay had a sensitivity of $90 \%$ for the detection of parvovirus B19-specific IgM and 98.9\% for the detection of the B19-specific IgG (personal communication). 
TABLE 2

Parvovirus B19 serology among pediatric patients and Red Cross blood donors

\begin{tabular}{|c|c|c|c|c|c|c|c|}
\hline \multirow[b]{2}{*}{ Age group (years) } & \multirow[b]{2}{*}{ Number } & \multicolumn{2}{|l|}{ Male } & \multicolumn{3}{|c|}{ Female } & \multirow[b]{2}{*}{$\begin{array}{c}\text { Total } \\
\text { positive }(\%)\end{array}$} \\
\hline & & IgG positive & Positive (\%) & Number & IgG positive & Positive (\%) & \\
\hline 1 to 5 & 15 & 0 & 0 & 15 & 1 & 6.6 & 3.3 \\
\hline 5 to 15 & 17 & 2 & 11.8 & 13 & 2 & 15.4 & 13.3 \\
\hline 15 to 25 & 15 & 4 & 26.7 & 15 & 6 & 40.0 & 33.3 \\
\hline 25 to 35 & 14 & 3 & 21.4 & 16 & 7 & 43.8 & 33.3 \\
\hline 35 to 45 & 15 & 8 & 53.3 & 15 & 12 & 80.0 & 66.7 \\
\hline 45 to 55 & 15 & 7 & 46.7 & 15 & 4 & 26.7 & 36.7 \\
\hline 55 to 65 & 15 & 3 & 20.0 & 15 & 7 & 46.7 & 33.3 \\
\hline Total & 106 & 27 & 25.5 & 104 & 39 & 37.5 & 31.4 \\
\hline
\end{tabular}

Ig Immunoglobulin

\section{RESULTS}

Seroprevalence: Of 494 sera tested for parvovirus B19 serology, virus-specific IgG antibody alone was detected in 120 samples and virus-specific IgM antibody alone was detected in 22 samples. An additional 76 sera were reactive for both antibodies (Table 1). No parvovirus B19-IgG antibody was detected in 276 sera. This category included sera for which repeatedly indeterminate results for B19 IgG and IgM were obtained. Sera having parvovirus B19-specific IgG as the only marker made up 24.3\% (120 of 494) of this population. If sera positive for B19-specific IgM were excluded from the above calculations, the prevalence of B19 IgG alone in the population was $30.3 \%$ (120 of 396). These sera are the most likely to represent acute or early convalescent infections.

To gain an insight into the seroprevalence of antibody to B19 in different age groups, a second group of sera was selected from pediatric patients and Red Cross blood donor specimens. The sera were stratified in groups of 30 specimens, representing equal numbers of males and females from seven age categories (Table 2). A total of 66 of these sera were positive for parvovirus B19 IgG, giving an overall seroprevalence of $31.4 \%$.

Age-specific seroprevalence: In the age stratified study, the prevalence of parvovirus B19 IgG was very low in the birth to five-year age group. It rose to $13.3 \%$ in the five to 15 -year group and to $33.3 \%$ in the 15 - to 25 -year age group. This prevalence rate persisted for subsequent age groups except for the 35- to 45-year group where it reached $66.7 \%$.

Sex-specific seroprevalence: When the prevalence of parvovirus B19-specific IgG in the age stratified study was analyzed by subjects' sex, it was higher in females of all ages except the 45to 55-year-old age group (Table 2 ). The average overall prevalence for males was $25.5 \%$ compared with $37.5 \%$ for the females, which was not statistically significant $\left(\chi^{2}\right.$ of 3.56 at 1 $\mathrm{df}, \mathrm{P}>0.05$ ). Of note, the prevalence of B19-specific IgG for both sexes in the 35- to 45-year-old age group was higher than other groups. In the 45- to 55-year-old age group, the prevalence of $46.7 \%$ in males compared with $26.7 \%$ in females was not statistically significant ( $\chi^{2} 1.3$ at $\left.1 \mathrm{df}, \mathrm{P}>0.05\right)$. Incidence of parvovirus B19 infection: Parvovirus B19specific IgM was detected throughout the year (Table 1), indi- cating that in this population infections most likely occur year-round. The highest monthly totals of B19-specific IgMpositive specimens in this study occurred from February to April, 1994.

\section{DISCUSSION}

On recovery from infection with parvovirus B19, most patients manifest an immune response of IgM and IgG antibody $(12,18)$. The presence of specific IgM is consistent with the patient experiencing an acute B19 infection. The presence of B19specific IgG in the absence of IgM is consistent with an infection in the remote past, with immunity to further infection. This immunity is currently considered to be lifelong $(18,19)$.

The above seroprevalence studies were performed using an enzyme immunoassay employing the recombinant parvovirus B19 antigen. When this assay was retrospectively compared with the commercial Biotrin assay, also based on the recombinant B19 antigen, the two assays were found to have comparable sensitivities. However, the commercial assay detected parvovirus B19-specific IgG in more sera. Therefore, the prevalence of antibody to parvovirus B19 found in our study should be viewed as a conservative value, and it may prove higher if more sensitive tests are used.

The presence of parvovirus B19-specific IgM in patient serum is generally associated with an ongoing or recent infection (20). The findings from the first population demonstrated that parvovirus B19 infections occur throughout the year. However, they also demonstrated that the infection rates are higher during the spring months, a finding consistent with previous reports (11).

The second group of patients was selected in an attempt to examine the prevalence of parvovirus B19-specific IgG in different age groups of the population. There are limitations to this selection because young children were registered as hospital patients and the older children were either in-patients or clinic out-patients. The sera from Red Cross blood donors came from adults whose health status did not preclude them from donating, but this may be representative of specific subsets of the population with a greater tendency for blood donation. Despite the above potential biases, these were the best populations readily available for testing. The fact that the overall prevalence 
of IgG antibody to B19 parvovirus was very similar for both the first and the second groups, who represent different populations, implied that the prevalence found in these studies is more likely to be representative of the population at large. Other studies reported similar prevalence rates $(12,14,20)$.

The relatively low prevalence of virus specific antibody in the under five-year-old age group reflected the fact that B19 infections are rare in early childhood and more common in adolescence where the largest rise in antibody prevalence was seen. The high prevalence (67\% in the 35 - to 45 -year-old age group) may reflect possible increased exposure because subjects in this age group are more likely to have adolescent children whose risk of B19 infections is high. This increased exposure may cause new infections in those who are not immune. Alternatively, it could result in asymptomatic reinfections with the boosting of antibody titres in subjects with low levels of immunity. The observation that seroprevalence increases with age has been reported in other studies $(12,14,18)$. The lower prevalence of virus-specific antibody in patients over 55 years of age may reflect a fall in antibody titre due to the waning of immunity with age. The marked change in prevalence in women between the 35to 45-year age group and the 45- to 55-year age group may repre-

\section{REFERENCES}

1. Anderson MJ, Lewis E, Kidd IM, Hall SM, Cohen BJ. An outbreak of erythema infectiosum associated with human parvovirus infection. J Hyg (Camb) 1984;93:85-93.

2. White DG, Woolf AD, Mortimer PP, Cohen BJ, Blake DR, Beacon PA. Human parvovirus arthropathy. Lancet 1985;i:419-21.

3. Reid DM, Reid TMS, Brown T, Rennie JAN, Eastmond CJ. Human parvovirus associated arthritis: A clinical and laboratory description. Lancet $1985 ; \mathrm{i}: 422-5$.

4. Brown T, Anand A, Ritchie LD, Clewley JP, Reid TMS. Intrauterine parvovirus infection associated with hydrops fetalis. Lancet 1984;ii:1033-4. (Lett)

5. Anand A, Gray ES, Brown T, Clewley JP, Cohen BJ. Human parvovirus infection in pregnancy and hydrops fetalis. N Engl J Med 1987;316:183-6.

6. Sergeant GR, Topley JM, Mason K, et al. Outbreak of aplastic crises in sickle cell anaemia associated with parvovirus-like agent. Lancet 1981;ii:595-7.

7. Chorba T, Coccia P, Holman RC, et al. The role of parvovirus B19 in aplastic crisis and erythema infectiosum (fifth disease). J Infect Dis 1986;154:383-93.

8. Kurtzman GJ, Cohen B, Meyers P, Amunullah A, Young NS. Persistent B19 parvovirus infection as a cause of severe chronic anemia in children with acute lymphocytic leukaemia. Lancet 1988;ii:1159-62.

9. Kurtzman GJ, Ozawa K, Cohen B, Hanson G, Oseas R, Young NS. Chronic bone marrow failure due to persistent B19 parvovirus infection. N Engl J Med 1987;317:287-94.

10. Pillay D, Patou G, Hurt S, Kibbler CC, Griffiths PD. Parvovirus B19 outbreak on a childrens' ward. Lancet 1992;339:107-9.

11. Plummer FA, Hammond GW, Forward K, et al. An erythema infectiosum-like illness caused by human parvovirus infection. N Engl J Med 1985;313:74-9. sent such a decrease in immunity because the later group is less likely to be in contact with adolescent children than the former. While evidence has been presented that IgG antibody to parvovirus B19 persists for life, very low levels may escape detection in an antibody capture assay such as the one used in this study $(13,14)$.

The prevalence of B19-specific IgG antibody was higher in females than in males, especially those between ages 15 and 45. This may reflect increased exposure of women to infected children of school age years, leading to asymptomatic reinfections and the boosting of the antibody response. Initial reports on erythema infectiosum recognized that females of all ages were more susceptible than males to this infection (21). Similar observations were reported in a study of 692 blood donors, aged 18 to 68 years, in which $32 \%$ of males were seropositive for parvovirus B19 antibody compared with $48 \%$ of females (22).

This study provides an insight into the prevalence of antibody to B19 parvovirus in Ontario. This information is important to the assessment of the relative risks of infection faced by this population when exposed to a patient with a parvovirus infection.
12. Anderson LJ. Role of parvovirus B19 in human disease. Pediatr Infect Dis J 1987;6:711-8.

13. Cohen BJ, Mortimer PP, Pereira MS. Diagnostic assays with monoclonal antibodies for human serum parvovirus-like virus (SPLV). J Hyg (Camb) 1983;91:113-30.

14. Anderson LJ, Tsou C, Parker RA, et al. Detection of antibodies and antigens of human parvovirus b19 by enzyme-linked immunosorbent assay. J Clin Microbiol 1986;24:522-6.

15. Karmali M, Petric M, Winkler M, et al. Enzyme-linked immunosorbent assay for detection of IgG antibodies to E coli verocytotoxin (VT). J Clin Microbiol 1994;32:1457-63.

16. Kajigaya S, Fujii H, Field A, et al. Self-assembled B19 parvovirus capsids produced in a baculovirus system are antigenically and immunologically similar to native virus. Proc Natl Acad Sci USA 1991;88:4646-50.

17. Norman GR, Steiner DL. PDQ Statistics, 1st edn. Toronto: BC Dekker Inc, 1986:172.

18. Erdman DD, Usher MJ, Tsou C, et al. Human parvovirus B19 specific IgG IgA and IgM antibodies and DNA from persons with erythema infectiosum. J Med Virol 1991;35:110-5.

19. Pattison JR. Parvoviruses medical and biological aspects. In: BN Fields, DM Knipe, RM Chanock, et al, eds. Virology, 2nd edn. New York: Raven Press, 1990:1765-84.

20. Cossart YE, Field AM, Cant B, Widdows D. Parvovirus-like particles in human sera. Lancet 1975;i:72-3.

21. Alder SP, Manganello A, Koch WC, Hempling SH, Best AL. Risk of human parvovirus B19 infections among school and hospital employees during endemic periods. J Infect Dis 1993;168:361-8.

22. Koch WC, Adler SP. Human parvovirus B19 infections in women of childbearing age and within families. Pediatr Infect Dis J 1989;8:83-7. 


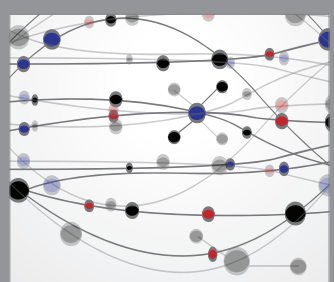

The Scientific World Journal
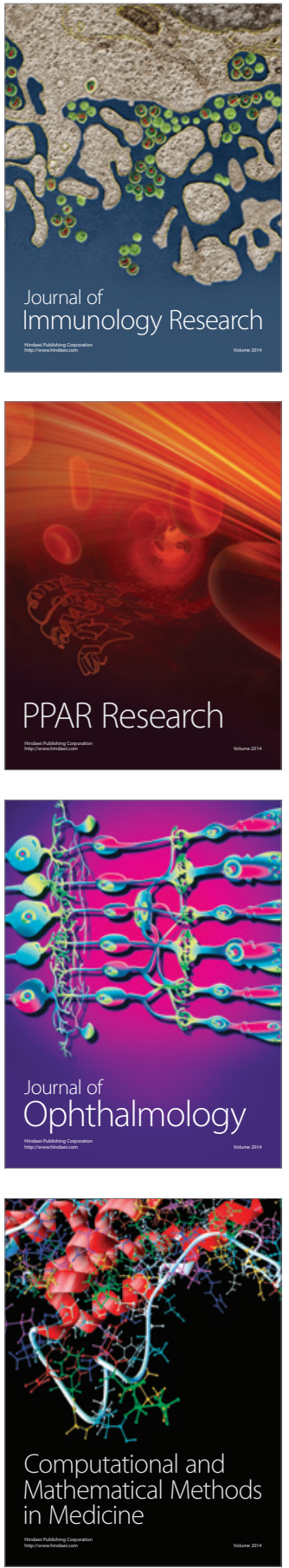

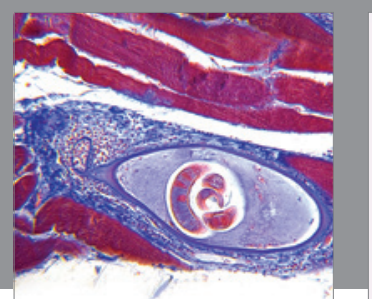

Gastroenterology Research and Practice

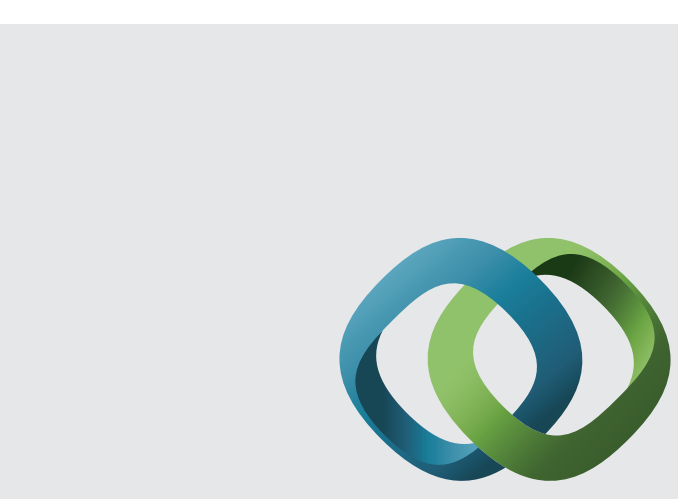

\section{Hindawi}

Submit your manuscripts at

http://www.hindawi.com
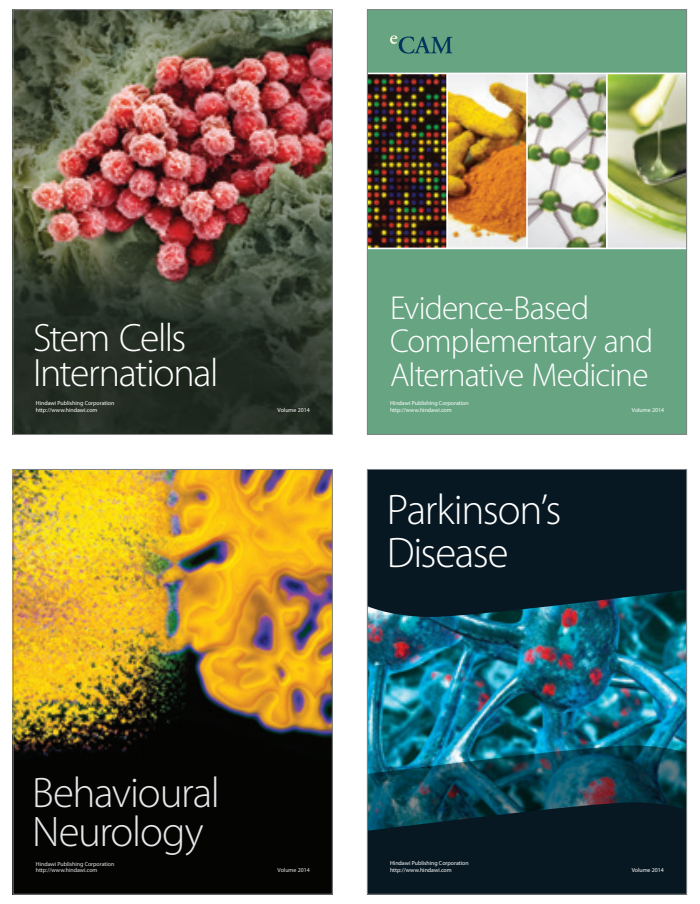
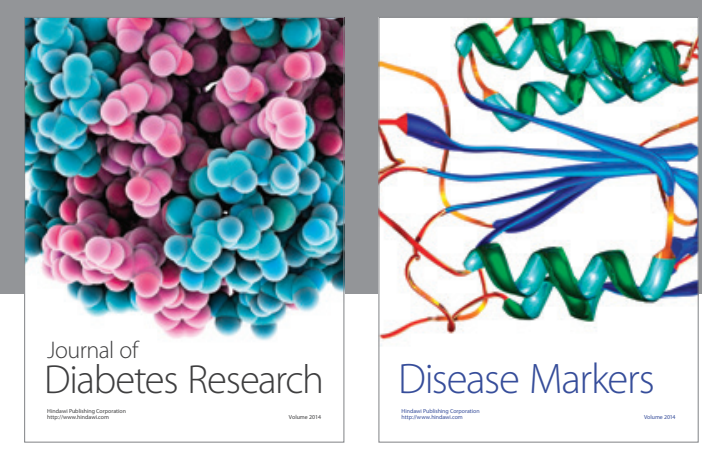

Disease Markers
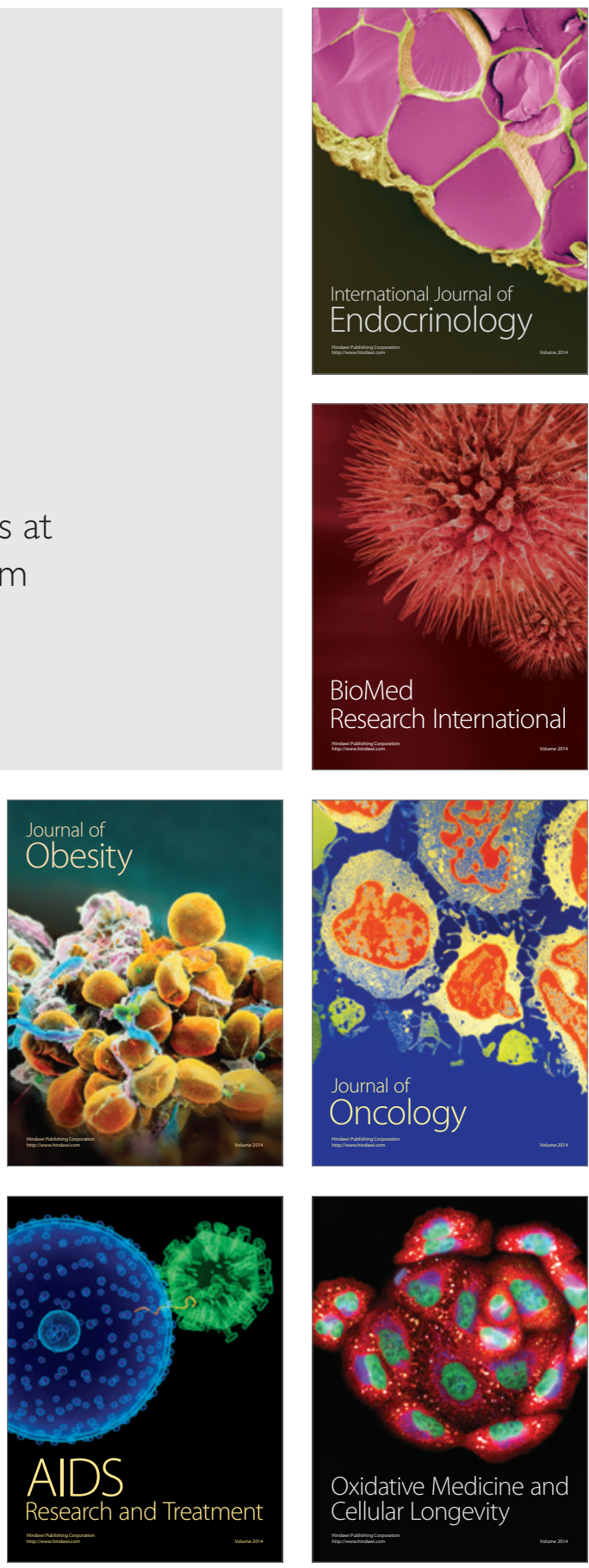